\title{
Overcoming barriers to the clinical utilization of iPSCs: reprogramming efficiency, safety and quality
}

\author{
Suying Cao ${ }^{1}$, Kyle Loh ${ }^{2}$, Yangli Pei ${ }^{1}$, Wei Zhang ${ }^{1}$, Jianyong Han ${ }^{1 凶}$ \\ ${ }^{1}$ State Key Laboratory for Agrobiotechnology, College of Biological Sciences, China Agricultural University, Beijing 100193, \\ China \\ ${ }^{2}$ Stem Cell and Developmental Biology, Genome Institute of Singapore, 138672, Singapore \\ $\triangle$ Correspondence: hanjy@cau.edu.cn
}

Received August 9, 2012 Accepted September 11, 2012

\begin{abstract}
Differentiated cells can be reprogrammed into pluripotent stem cells, known as "induced pluripotent stem cells" (iPSCs), through the overexpression of defined transcription factors. The creation of iPSC lines has opened new avenues for patient-specific cell replacement therapies for regenerative medicine. However, the clinical utilization of iPSCs is largely impeded by two limitations. The first limitation is the low efficiency of iPSCs generation from differentiated cells. The second limitation is that many iPSC lines are not authentically pluripotent, as many cell lines inefficiently differentiate into differentiated cell types when they are tested for their ability to complement embryonic development. Thus, the "quality" of iPSCs must be increased if they are to be differentiated into specialized cell types for cell replacement therapies. Overcoming these two limitations is paramount to facilitate the widespread employment of iPSCs for therapeutic purposes. Here, we summarize recent progress made in strategies enabling the efficient production of high-quality iPSCs, including choice of reprogramming factors, choice of target cell type, and strategies to improve iPSC quality.
\end{abstract}

KEYWORDS iPSCs, reprogramming, embryonic stem cells, efficiency and quality

\section{INTRODUCTION}

The zygote and the embryonic blastomeres are totipotent cells, as they are capable of generating all embryonic and extraembryonic tissues that give rise to an entire organism. After 4.5 days of embryonic development, these totipotential cells give rise to three distinct cell types that comprise the blastocyst-stage embryo: the epiblast, the primitive endoderm, and the trophectoderm. Of these blastocyst cell types, only the cells of epiblast retain the capacity to generate all cell types of the three fetal germ layers: the definitive endoderm, mesoderm, and definitive ectoderm, as well as the primordial germ cells (PGC), the founder cells of male and female gametes. Given the capacity of epiblast to give rise to all fetal cell types, it is pluripotent.

Embryonic stem (ES) cells, cultured cell lines explanted from the epiblast, are also pluripotent, as they are capable in vitro of generating cell types from all three fetal germ layers, as well as differentiating into male and female germ cells (Wobus and Boheler, 2005). When transplanted back into the early embryo into their native environment, ES cells are receptive to developmental patterning signals and they subsequently differentiate into fetal cell types and contribute to fetal development. The pluripotency of ES cells are lost as they differentiate to generate their differentiated progeny.

Nevertheless, differentiated cells can be coerced to re-attain an unrestricted pluripotent state. Herein, we refer to this process as "pluripotent reprogramming". There are different strategies that have been used to induce the conversion of a differentiated cell into a pluripotent state, including nuclear transfer, fusion with pluripotent cells, co-culture with cell extracts, culture-induced reprogramming, and overexpression of defined transcription factors (Hochedlinger and Jaenisch, 2006; Takahashi and Yamanaka, 2006).

Somatic cell nuclear transfer (SCNT), whereby the nu- 
cleus of a differentiated cell is transplanted into an enucleated oocyte or zygote, recreates something akin to a totipotential cell. The differentiated gene expression program of the nucleus of the differentiated cell is erased by nuclear factors present in the cytoplasm of the enucleated oocyte, and the presence of these oocyte nuclear factors reinstates a totipotential gene expression program within the new hybrid cell formed by nuclear transfer. The resultant totipotent cell resumes normal embryonic development and forms a blastocyst from which ES cells can be derived. Thus, SCNT allows for the indirect reprogramming of a differentiated cell into a pluripotent cell. Nevertheless, there are technical and ethical issues in applying SCNT to human cells to create pluripotent human cells through this method (Hochedlinger and Jaenisch, 2006; Yamanaka, 2007).

Fusion of a differentiated cell with a pluripotent cell to reprogram the former into a pluripotent cell is also undesirable, as the resultant cell has a tetraploid karyotype. Reprogramming of differentiated cells by exposure to pluripotent cell extracts has been unsuccessful to date in creating authentic pluripotent cells, and reprogramming by specific culture conditions is limited to germ cell lines (Hochedlinger and Jaenisch, 2006).

To date, the most compelling method to achieve pluripotent reprogramming is through the overexpression of pluripotency-associated transcription factors within differentiated cells. Similar to how in SCNT that oocyte nuclear factors enter into the differentiated cell's nucleus to construct a totipotential gene expression program, in this approach to pluripotent reprogramming, the overexpressed pluripotency-associated transcription factors enter the nucleus of the differentiated cell and instate a pluripotential gene expression program.

In the original report of using transcription factor overexpression to achieve pluripotential reprogramming, Takahashi and Yamanaka were able to reprogram mouse fibroblasts into pluripotent stem cells, known as "induced pluripotent stem cells" (iPSCs), by the overexpression of four pluripotency-associated transcription factors (Oct4, Sox2, Klf4, and $c-M y c)$ (Takahashi and Yamanaka, 2006).

Our capability to create iPSCs through transcription factor overexpression has yielded several outstanding benefits. Firstly, the creation of iPSCs through the reprogramming of adult cells allows for the creation of pluripotent stem cell lines bereft of any embryonic tissues or oocytes, thus circumventing many previous ethical objections to the derivation of ES cells from embryos. Secondly, the derivation of "patient specific" iPSCs from the adult tissues of human patients creates immune-matched iPSC lines that are autologous to the donor patient; any differentiated progeny cells generated from these patient-specific iPSC lines are immunocompatible to the patient and thus can be used in a cell replacement therapy without permanent immunosuppression. Finally, the creation of patient-specific iPSC lines from patients afflicted with cer- tain genetic diseases allows for the in vitro modeling of these diseases. Other benefits of iPSC research are expertly reviewed elsewhere.

Recent advances in iPSC research are summarized in this review with a focus on different strategies that have been used to reprogram differentiated cells into iPSCs, the identification of nuclear factors and chemical compounds that can enhance the efficiency of pluripotential reprogramming, and lastly, the identification of factors which uniformly improve the "quality" of iPSCs and allow for more consistent creation of authentically pluripotent iPSC lines. The potential mechanisms of direct reprogramming at the molecular and biochemical levels and future directions of iPSC research are also discussed.

\section{STRATEGIES FOR IPSC GENERATION}

A variety of strategies exist for direct reprogramming differentiated cells to pluripotent state, all of which rely on overexpression of particular transcription factors (Table 1).

One question that has been well-addressed by the field is what is the best technical method by which to overexpress these reprogramming transcription factors within the starting cells. The production of iPSCs has so far been achieved through nucleic-acid-based delivery of the reprogramming factors (Maherali and Hochedlinger, 2008). Initial generations of mouse and human iPSCs employed retroviral vectors (Takahashi and Yamanaka, 2006; Takahashi et al., 2007) and constitutive lentiviruses (Blelloch et al., 2007; Yu et al., 2007), while later generations were produced using inducible lentiviruses (Brambrink et al., 2008; Stadtfeld et al., 2008b). Residual expression of integrated copies of reprogramming factors in iPSCs can affect the gene expression and potentially biological properties of the resulting iPSC derivatives. These viral systems, however, have been criticized for their permanent integration into the genome, and endeavors to make iPSCs more therapeutically applicable have led to the pursuit of non-integrating approaches (Maherali and Hochedlinger, 2008).

The first reports at direct reprogramming employed Moloney-based retroviral vectors that are known to undergo silencing in the ESC state (Takahashi and Yamanaka, 2006; Takahashi et al., 2007; Yu et al., 2007); this self-silencing property provided an advantage for initial attempts as the temporal requirement of factor expression, which was defined that proviral silencing in embryonic stem cells requires the histone methyltransferase Eset (Maherali and Hochedlinger, 2008; Matsui et al., 2010). There are several drawbacks for the genome integration system for example their infectivity is limited to dividing cells, thus restricting the range of cell types that can be reprogrammed; silencing occurs gradually during the course of iPSC induction, resulting in a lowered efficiency of conversion compared to nonsilencing viral methods and iPSCs made with retroviruses often maintain viral gene ex- 
Table 1 Summary of strategies enabling the production of iPSCs

\begin{tabular}{|c|c|c|c|}
\hline Strategy & & Characters & References \\
\hline \multirow[t]{3}{*}{ Genomic integration } & Moloney-based retrovirus & $\begin{array}{l}\text { Silenced in pluripotent cells; genomic inte- } \\
\text { gration; limited to dividing cells }\end{array}$ & Takahashi and Yamanaka, 2006 \\
\hline & $\begin{array}{l}\text { HIV-based lentivirus; consti- } \\
\text { tutive system }\end{array}$ & $\begin{array}{l}\text { Genomic integration; lack of silencing in } \\
\text { pluripotent state; transduction of both divid- } \\
\text { ing and nondividing cells }\end{array}$ & $\begin{array}{l}\text { Blelloch et al., 2007; Yu et al., 2007; } \\
\text { Brambrink et al., } 2008\end{array}$ \\
\hline & Inducible system & $\begin{array}{l}\text { Genomic integration; possibility of leaky } \\
\text { expression; temporal control over factor } \\
\text { expression }\end{array}$ & $\begin{array}{l}\text { Brambrink et al., 2008; Stadtfeld et } \\
\text { al., } 2008 \text { b }\end{array}$ \\
\hline \multirow[t]{6}{*}{$\begin{array}{l}\text { Free of genetic } \\
\text { modification }\end{array}$} & Transient transfection & $\begin{array}{l}\text { No viral components, low frequency of ge- } \\
\text { nomic integration, technically simple proce- } \\
\text { dure but multiple rounds of transfection are } \\
\text { required, delayed kinetics of reprogramming }\end{array}$ & Okita et al., 2008 \\
\hline & Lentiviral vectors + Cre & $\begin{array}{l}\text { Efficient reprogramming and vector deletion } \\
\text { but Vector DNA external to the loxP sites } \\
\text { remain integrated }\end{array}$ & $\begin{array}{l}\text { Chang et al., 2009; Soldner et al., } \\
2009\end{array}$ \\
\hline & $\begin{array}{l}\text { Adenoviral vector, Episomal } \\
\text { vectors, Sendai vectors }\end{array}$ & $\begin{array}{l}\text { Low frequency of genomic integration, de- } \\
\text { layed kinetics of reprogramming, some gen- } \\
\text { eration of tetraploid cells }\end{array}$ & $\begin{array}{l}\text { Stadtfeld et al., 2008c; Fusaki et al., } \\
\text { 2009; Gonzalez et al., } 2009\end{array}$ \\
\hline & piggyBac transposon & $\begin{array}{l}\text { Precise deletion possible, excision may be } \\
\text { inefficient and laborious }\end{array}$ & Kaji et al., 2009; Woltjen et al., 2009 \\
\hline & Protein transduction & $\begin{array}{l}\text { Direct delivery of transcription factors avoids } \\
\text { complications of nucleic-acid-based delivery, } \\
\text { but not yet reported for iPSC production }\end{array}$ & Bosnali and Edenhofer, 2008 \\
\hline & Small molecules & $\begin{array}{l}\text { No genetic modification, still requires at least } \\
\text { one factor to be transduced }\end{array}$ & $\begin{array}{l}\text { Huangfu et al., 2008a; Shi et al., } \\
2008 \text { b; Ichida et al., 2009; Lyssiotis } \\
\text { et al., } 2009\end{array}$ \\
\hline
\end{tabular}

pression thus limiting their utility (Maherali and Hochedlinger, 2008). Although iPSCs can be generated by constitutive lentiviruses, their poor silencing within pluripotent cells make them less suitable for direct reprogramming attempts (Blelloch et al., 2007; Yu et al., 2007; Brambrink et al., 2008). Drug-inducible lentiviruses have provided a more attractive approach, as they permit temporal control over factor expression. This approach creates a defined system for studying reprogramming mechanisms and allows screening of genetically homogeneous cells for compounds that can replace any transcription factor that enhance reprogramming efficiency or required for iPS cell derivation (Wernig et al., 2008; Markoulaki et al., 2009; Wu et al., 2009). In these systems, proviruses carrying drug-inducible reprogramming factors used to derive 'primary' iPSCs were segregated through germ line transmission, generating mice and cells carrying subsets of the reprogramming factors. Drug treatment produced 'secondary' iPS cells with over 100-fold increase efficiency only when the missing factor was introduced (Markoulaki et al., 2009).

Methods to overexpress the reprogramming factors that rely on genomic integration within the starting cells have earned much criticism, as the resultant iPSCs also carry the same genomic integrations. The very presence of viral integrations within the genome elicits insertional mutagenesis and reactivation of proximal oncogenes, thus drastically altering cellular properties such as proliferation rate (Kustikova et al., 2005). Furthermore, after such iPSCs are differentiated and the pluripotent state is exited, the silenced integrated reprogramming factors can be reactivated within the subsequent differentiated cells-thus, when such iPSCs are used to form chimeras, the resultant chimeras had a proclivity for tumorigenesis, likely due to spontaneous reactivation of the reprogramming factor $c-M y c$, which is an oncogene (Nakagawa et al., 2008).

Though it was originally suggested that the very process of iPSC generation might entail transgene integration into particular loci, it was found shortly thereafter that there are no common integration sites amongst various retrovirally-induced IPSC lines, suggesting that transgene integration is not a necessary reprogramming step and that generation of insertion-free iPSCs is possible (Aoi et al., 2008; Varas et al., 2009). This notion has been confirmed by a series of studies. Yu et al. generated human iPS cells with the use of nonintegrating episomal vectors. After removal of the episome, iPS cells completely free of vector and transgene sequences are derived that are similar to human embryonic stem (ES) cells in proliferative and developmental potential (Yu et al., 2009). Stadtfeld et al. derived mouse induced pluripotent stem (iPS) cells from fibroblasts and liver cells by using nonintegrating adenoviruses transiently expressing Oct4, Sox2, Klf4, and c-Myc. These adenoviral iPS (adeno-iPS) cells show DNA demethylation characteristic of reprogrammed cells, express endogenous pluripotency genes, form teratomas, and contribute to multiple tissues, including the germ line, in chimeric mice (Stadtfeld et al., 
2008c). Just by repeated transient transfection of plasmids carrying the reprogramming factors, Okita et al. also attained insertion-free mouse iPS similar to ES cells.

Such episomal, adenoviral, and transient transfection means to deliver the reprogramming factors address a critical safety concern for the potential use of iPS cells in regenerative medicine (Okita et al., 2008). Although the several methods above are transient and minimize the potential for insertion mutagenesis, it should be noted that they are extremely inefficient in reprogramming cells as compared to traditional integrating vector strategies.

Other groups have exploited lentiviral vectors flanked by loxP sites as factor delivery vehicles, such that Cre-mediated recombination in the resultant iPSC lines could excise the integrated transgenes (although it should be noted that the loxP sites themselves remain in the genome) (Chang et al., 2009; Soldner et al., 2009). Another recent approach has involved piggyBac transposition, wherein the reprogramming factors are delivered in a piggyBac transposon that can be subsequently induced to integrate or excise from the genome upon transient expression of a transposase enzyme (Kaji et al., 2009; Woltjen et al., 2009). Unlike the above loxP-based lentiviral system, the piggyBac transposition system does not leave behind any genetic material in the genome after transposon excision.

\section{REPROGRAMMING WITH DIFFERENT FACTORS OF TRANSCRIPTION FACTORS}

In their original report where Takahashi and Yamanaka that found that transcription factor overexpression was capable of reprogramming mouse fibroblasts, they screened 24 transcription factors, intracellular signaling pathway components, and epigenetic regulators believed to be important in safeguarding the pluripotency of ES cells. Through iterative experiments, they eventually found that all factors save four were dispensable for reprogramming - these four factors became known as the classical quartet of pluripotential reprogramming factors; Oct4, Sox2, Klf4, and c-Myc (Takahashi and Yamanaka, 2006). This classical cocktail of reprogramming factors has been shown to induce pluripotency within a multitude of mouse cell types, as well as rhesus monkey (Li et al., 2009b; Liao et al., 2009), pig (Esteban et al., 2009; Ezashi et al., 2009; Wu et al., 2009; West et al., 2010) and human cells (Takahashi et al., 2007; Yamanaka, 2007).

Permutations of this classic four-factor combination have been used to successfully reprogram differentiated cells to a pluripotent state (Table 2). For example, Sox 1 and Sox 3 have been found to be able to substitute for Sox2, albeit with a decrease in reprogramming efficiency; KIf2 can replace Klf4, and $L-M y c$ and $N-M y c$ were found to be able to replace $c-M y c$ (Blelloch et al., 2007; Nakagawa et al., 2008). Yu et al. was also able to generate human iPSCs from human fibroblasts through a different set of factors, namely Oct4, Sox2, Nanog, and Lin28 (Yu et al., 2007).

Later, $c-M y c$ was found to be dispensable for the reprogramming process, thus further narrowing down the list of classical reprogramming factors to three-Oct4, Sox2, and Klf4 (Blelloch et al., 2007).

Certain reprogramming factors have been found to be dispensible when cell types endogenously expressing these reprogramming factors are used, thus further reducing the number of necessary factors. For example, human and mouse neural stem cells already express Sox2, Klf4, and $c-M y c$; thus, they can be reprogrammed by singular overexpression of Oct4 (Kim et al., 2008, 2009b).

Other unrelated pluripotency-associated transcription factors have also been shown to be capable of reprogramming cells. For example, we have found that Klf4 can be replaced by the orphan nuclear receptor Esrrb, thus allowing for reprogramming with only Oct4 and Sox2 (Feng et al., 2009a). Overexpression of the orphan nuclear receptor $\mathrm{Nr} 5 \mathrm{a} 2$ can replace Oct4, thus allowing for reprogramming with only Sox2 and Klf4 (Heng et al., 2010).

Of particular interest, transcription factor overexpression is a feasible approach to establish pluripotent stem cell lines for species in which it has been difficult to establish ES cell lines from the early embryo (Trounson, 2009; Wu et al., 2009). For example, ES cell lines of many species, such as pig, cow, goat, and sheep have been long sought-after, and many efforts to produce ES cell lines for these species over the past two decades have proven to be unsuccessful (Keefer et al., 2007).

Despite this, pluripotent stem cell lines for the rat, pig and monkey in the form of iPSC lines have been derived through the overexpression of Oct4, Sox2, Klf4, and c-Myc from these species (Liu et al., 2008; Esteban et al., 2009; Ezashi et al., 2009; Li et al., 2009b; Liao et al., 2009; Wu et al., 2009). However, we note that some caution must be taken when considering these iPSC lines from such species, because the pluripotential character of such species' iPSC lines is not comparable with the pluripotent character of conventional mouse ES and iPSC cell lines. For example, pig iPSCs do not exhibit as robust reactivation of endogenous pluripotency genes as mouse iPSCs, and they are incapable of silencing integrated genes (Esteban et al., 2009; Ezashi et al., 2009; Wu et al., 2009). Nevertheless, porcine iPSCs derived from mesenchymal cells are capable of contribution to all three germ layers after injection into the early embryo, affirming that they at least are capable of multilineage differentiation (West et al., 2010).

\section{CHOICE OF STARTING CELL TYPE}

As aforementioned, the choice of starting cell type to be used for reprogramming is impactful. Cells that already endogenously express certain reprogramming factors at appropriate 
levels may not require overexpression of these factors during the reprogramming process. Furthermore, stem cells and progenitors often have a more globally permissive chromatin structure to facilitate ready access to multilineage differentia-

Table 2 Different combinations of transcription factors that induce nuclear reprogramming

\begin{tabular}{|c|c|c|c|c|}
\hline Species & Combination of factors & Cell types & Comments & Reference \\
\hline \multirow[t]{11}{*}{ Mouse } & OSKMc & $\begin{array}{l}\text { Most of the cell types } \\
\text { including terminal dif- } \\
\text { ferentiated } B \text { and } T \\
\text { cells }\end{array}$ & $\begin{array}{l}\text { Yamanaka's classical cocktail of reprogram- } \\
\text { ming factors }\end{array}$ & $\begin{array}{l}\text { Takahashi and Yamanaka, } \\
\text { 2006; Aoi et al., 2008; } \\
\text { Hanna et al., 2008; Kim et } \\
\text { al., 2008; Stadtfeld et al., } \\
\text { 2008a }\end{array}$ \\
\hline & OSKMn & Fibroblast & $\begin{array}{l}\text { nMyc and cMyc are largely interchangeable } \\
\text { and nMyc has been reported to be less tu- } \\
\text { morigenic than cMyc in in vitro assays of } \\
\text { transformation }\end{array}$ & Blelloch et al., 2007 \\
\hline & OSKT & Fibroblast & $\begin{array}{l}\text { Tbx3 can improve the quality of iPS cells due } \\
\text { to its regulation of pluripotency associated } \\
\text { and reprogramming factors }\end{array}$ & Han et al., 2010 \\
\hline & OSEMc & Fibroblast & $\begin{array}{l}\text { Esrrb is a orphan nuclear receptor, it may } \\
\text { mediate reprogramming through the upregula- } \\
\text { tion of ES-cell-specific genes }\end{array}$ & Feng et al., 2009a \\
\hline & SKNrMc & Fibroblast & $\begin{array}{l}\text { Nr5a2 shares many common gene targets with } \\
\text { Sox } 2 \text { and Klf4, can upregulate Nanog in ES cells }\end{array}$ & Heng et al., 2010 \\
\hline & OSK & $\begin{array}{l}\text { Fibroblast, hepatocytes } \\
\text { and neural stem cells }\end{array}$ & $\begin{array}{l}\text { Ectopic expression of c-Myc causes tumori- } \\
\text { genicity in chimeric offspring }\end{array}$ & Nakagawa et al., 2008 \\
\hline & OSE & Fibroblast & Low efficiency & Feng et al., 2009a \\
\hline & $\mathrm{SKNr}$ & Fibroblast & Low efficiency & Heng et al., 2010 \\
\hline & OK & Neural stem cell & $\begin{array}{l}\text { Neural stem cells express higher endogenous } \\
\text { levels of Sox } 2 \text { and c-Myc than embryonic stem } \\
\text { cells }\end{array}$ & Kim et al., 2008 \\
\hline & OMc & Neural stem cell & $\begin{array}{l}\text { Neural stem cells express higher endogenous } \\
\text { levels of Sox } 2 \text { and Klf } 4\end{array}$ & Kim et al., 2008 \\
\hline & $\mathrm{O}$ & Neural stem cell & $\begin{array}{l}\text { Neural stem cells express higher endogenous } \\
\text { levels of Sox } 2 \text { and Klf } 4\end{array}$ & Kim et al., $2009 \mathrm{~b}$ \\
\hline \multirow[t]{8}{*}{ Human } & OSKMc & Most of the cell types & $\begin{array}{l}\text { Yamanaka's classical cocktail of reprogram- } \\
\text { ming factors }\end{array}$ & $\begin{array}{l}\text { Takahashi et al., 2007; } \\
\text { Aasen et al., 2008; Lowry } \\
\text { et al., 2008; Park et al., } \\
\text { 2008; Loh et al., } 2009\end{array}$ \\
\hline & OSNL & Dermal fibroblasts & Yu's cocktail for human direct reprogramming & Yu et al., 2007 \\
\hline & OSK & Dermal fibroblasts & $\begin{array}{l}\text { Myc is independent for human direct } \\
\text { reprogramming }\end{array}$ & $\begin{array}{l}\text { Takahashi et al., } 2007 \text {; } \\
\text { Huangfu et al., 2008b }\end{array}$ \\
\hline & OKN & Dermal fibroblasts & Low efficiency & Yu et al., 2007 \\
\hline & OKL & Dermal fibroblasts & Low efficiency & Yu et al., 2007 \\
\hline & OS + VPA & Dermal fibroblasts & $\begin{array}{l}\text { Valproic acid (VPA), a histone deacetylase } \\
\text { inhibitor, enables reprogramming of primary } \\
\text { human fibroblasts with only two factors, Oct } 4 \\
\text { and Sox2 }\end{array}$ & Huangfu et al., 2008b \\
\hline & OKMc & Neural stem cell & $\begin{array}{l}\text { Neural progenitor cells expressed high levels } \\
\text { of endogenous Sox } 2 \text { and thus did not require } \\
\text { viral Sox } 2 \text { expression for reprogramming into } \\
\text { iPS cells }\end{array}$ & $\begin{array}{l}\text { Eminli et al., 2008; Kim et } \\
\text { al., } 2008\end{array}$ \\
\hline & $\mathrm{O}$ & Neural stem cell & $\begin{array}{l}\text { Neural stem cells express higher endogenous } \\
\text { levels of Sox } 2 \text { and Klf } 4\end{array}$ & $\begin{array}{l}\text { Kim et al., 2008; Kim et al., } \\
2009 a\end{array}$ \\
\hline Rat & OSKMc & Fibroblast & $\begin{array}{l}\text { Rat adult cell can be reprogrammed to pluripotent } \\
\text { state by mouse and human transcription factors }\end{array}$ & Liu et al., 2008 \\
\hline Monkey & OSKMc & Fibroblast & $\begin{array}{l}\text { Monkey iPS cells need further test of chimera } \\
\text { contribution }\end{array}$ & $\begin{array}{l}\text { Li et al., 2009b; Liao et al., } \\
2009\end{array}$ \\
\hline Pig & $\begin{array}{l}\text { OSKMc } \\
\text { OSKMcNL }\end{array}$ & $\begin{array}{l}\text { Fibroblast } \\
\text { Mesenchymal cells }\end{array}$ & $\begin{array}{l}\text { Pig adult cell can be reprogrammed to pluri- } \\
\text { potent state by human transcription factors }\end{array}$ & $\begin{array}{l}\text { Esteban et al., 2009; } \\
\text { Ezashi et al., 2009; Wu et } \\
\text { al., 2009; West et al., } 2010\end{array}$ \\
\hline
\end{tabular}

Note: O, Oct4; S, Sox2; K, KIf4; Mc, c-Myc; Mn, n-Myc; E, Esrrb; Nr, Nr5a2; N, Nanog; L, Lin28 
tion programs, thus making them more amenable to reprogramming. Additionally, differentiated cells with extensive self-renewal capabilities or that express certain pluripotency markers or transcriptional regulators may also be more inclined towards pluripotential reprogramming.

Through conventional reprogramming approaches, human and mouse fibroblasts can only be reprogrammed with a $0.01 \%-0.05 \%$ efficiency (Takahashi and Yamanaka, 2006; Takahashi et al., 2007; Yu et al., 2007). However, results from multiple independent laboratories indicated that neural stem cells (Kim et al., 2008), hematopoietic stem cells (Eminli et al., 2009), meningiocytes from the mouse meningeal membranes (Qin et al., 2008) and primary keratinocytes from plucked hair (Aasen et al., 2008) are more efficiently reprogrammed utilizing the same reprogramming protocols (Table 3 ).

For at least some of these cell types, it is likely that their increased proclivity for reprogramming is due to endogenous expression of the reprogramming genes. For example, human keratinocytes already express very high levels of KIf4 and $c-M y c$, and they reprogram two orders of magnitude more efficiently than their fibroblast counterparts (Aasen et al., 2008). Mouse meningial membrane cells already express Sox2, thus providing a mechanistic explanation for their relatively high reprogramming efficiency (Qin et al., 2008).

Conversely, particular differentiated cell types appear to be more refractory to reprogramming. For example, efficient reprogramming of terminally-differentiated $B$ lymphocytes requires knockdown of the $B$ lymphocyte transcription factor Pax5 or overexpression of the myeloid transcription factor C/EPBa to destabilize the firmly-entrenched B cell transcriptional program prior to reprogramming (Hanna et al., 2008).

Several laboratories have established differentiated cell lines that already uniformly carry doxycycline-inducible copies of the reprogramming genes; these cell lines efficiently reprogram upon addition of doxycycline and their reprogram- ming efficiency does not depend on variable efficiency by which the reprogramming factors can be overexpressed using viral vectors (Hanna et al., 2008). Thus, true reprogramming efficiency of these cells invariant of viral infection efficiency can be ascertained. Such high-efficiency "secondary systems" are attained through iPSCs that have been generated with integrated, doxycycline-inducible reprogramming factors; these "primary" iPSCs are differentiated into differentiated cells, such that addition of doxycycline reprograms these cells into "secondary" iPSCs.

Irrespective of what cell types are ideal for highly efficient pluripotent reprogramming, if we wish to derive patient-specific iPSC lines from human patients, our choice of starting cell type must be predicated on what cell types we can routinely explant from such patients. For example, though neural stem cells reprogram with extremely high efficiency, it would be infeasible to routinely explant neural stem cells from human patients. To this end, a recent breakthrough has been the induction of human iPSCs from human mobilized CD34+ peripheral blood cells (Loh et al., 2009). Our capability to attain iPSCs from hematopoietic cells enables the production of patient-specific iPSCs from blood samples taken from such patients.

\section{Enhancing reprogramming efficiency by alternative factors}

The efficiency of pluripotential reprogramming can be enhanced by the inclusion of various other factors besides pluripotent transcription factors. These alternative factors, including microRNAs and chemical compounds, either safeguard the pluripotential identity of ES cells (and thus are likely to impose pluripotency within a differentiated cell) or else play more specific roles in facilitating the reprogramming process but not maintaining pluripotency after it is established (Table 4).

Table 3 The choice of cell type for iPSCs

\begin{tabular}{|c|c|c|c|}
\hline Species & Cell types & Efficiency & Reference \\
\hline \multirow[t]{7}{*}{ Mouse } & Embryonic fibroblast and adult tail fibroblast & $0.01 \%-0.05 \%$ & Takahashi and Yamanaka, 2006 \\
\hline & Adult mouse hepatocytes and gastric epithelial cells & & Aoi et al., 2008 \\
\hline & Pancreatic $\beta$-cells & $0.1 \%-0.2 \%$ & Stadtfeld et al., 2008a \\
\hline & Meningiocytes & $0.5 \%-0.8 \%$ & Qin et al., 2008 \\
\hline & Mature B-lymphocytes & $3 \%$ & Hanna et al., 2008 \\
\hline & Neural stem cells & $3.6 \%$ & Kim et al., 2008; Eminli et al., 2009 \\
\hline & Hematopoietic stem cells & $28 \%$ & \\
\hline \multirow[t]{5}{*}{ Human } & $\begin{array}{l}\text { IMR90 fetal fibroblasts; mesenchymal and myeloid cells from hu- } \\
\text { man OCT4 knock-in H1 ES cells }\end{array}$ & $0.01 \%-0.05 \%$ & Yu et al., 2007 \\
\hline & Dermal fibroblasts and BJ cells & $0.02 \%-0.05 \%$ & Takahashi et al., 2007 \\
\hline & CD34+ mobilized human peripheral blood cells & $0.01 \%-0.02 \%$ & Lowry et al., 2008 \\
\hline & Fetal, neonatal and adult fibroblasts & $0.1 \%$ & Loh et al., 2009 \\
\hline & Primary keratinocytes from plucked hair & $0.36 \%$ & Park et al., 2008; Aasen et al., 2008 \\
\hline Monkey & Adult rhesus monkey fibroblasts & $<0.01 \%$ & Liu et al., 2008 \\
\hline Rat & Rat fibroblast & $<0.01 \%$ & Li et al., 2009b; Liao et al., 2009 \\
\hline Pig & $\begin{array}{l}\text { Pig fibroblast } \\
\text { Mesenchymal cells }\end{array}$ & $<0.01 \%$ & $\begin{array}{l}\text { Esteban et al., 2009; Ezashi et al., } \\
\text { 2009; Wu et al., 2009; West et al., } 2010\end{array}$ \\
\hline
\end{tabular}


Table 4 Factors used to enhance direct reprogramming efficiency

\begin{tabular}{|c|c|c|c|}
\hline Factors & & Comments & References \\
\hline \multirow[t]{3}{*}{ MicroRNAs } & Mir-302 & $\begin{array}{l}\text { mir-302, which is expressed abundantly in human ESCs, is able to } \\
\text { convert human cancer cells into an ES-like pluripotent state, also } \\
\text { maintain this state under a feeder-free cultural condition }\end{array}$ & Lin et al., 2008 \\
\hline & $\begin{array}{l}\text { Mir-291-3p; } \\
\text { Mir-294, } 295\end{array}$ & $\begin{array}{l}\text { The miRNAs increase the efficiency of reprogramming by Oct } 4 \text {, Sox } 2 \\
\text { and Klf4, but not by these factors plus cMyc; induce a homogeneous } \\
\text { population of iPS cell colonies comparing with cMyc }\end{array}$ & Judson et al., 2009 \\
\hline & $\begin{array}{l}\text { Inhibition of the } \\
\text { let-7 family }\end{array}$ & $\begin{array}{l}\text { let-7 miRNAs highly expressed in somatic cells-can suppress } \\
\text { self-renewal in Dgcr8 } \\
\text { ESCC miRNAs indirectly activate numerous self-renewal genes and } \\
\text { inhibition of the let-7 family promotes de-differentiation of somatic cells } \\
\text { to induced pluripotent stem cells }\end{array}$ & Melton et al., 2010 \\
\hline \multirow[t]{11}{*}{ Chemicals } & $\begin{array}{l}\text { 2i,CHIR99021+ } \\
\text { PD0325901 }\end{array}$ & $\begin{array}{l}\text { Dual inhibition of MEK and GSK3, together with LIF, promote ground } \\
\text { state pluripotentcy in OK pre-iPSCs in mouse neural stem cells }\end{array}$ & Silva et al., 2008 \\
\hline & BIX-01294 & $\begin{array}{l}\text { G9a histone methyltransferase inhibitor, can replace sox } 2 \text { in mouse } \\
\text { fibroblast reprogramming and can enhance efficiency of reprogramming } \\
\text { and replace sox } 2 \text { in neural stem cells }\end{array}$ & Shi et al., 2008a, 2008b \\
\hline & BayK8644 & $\begin{array}{l}\text { L-type calcium channel agonist, BIX-01294 and BayK8644combination } \\
\text { with factors OK enhance reprogramming efficiency }\end{array}$ & Shi et al., 2008a \\
\hline & RG108 & $\begin{array}{l}\text { DNA methyltransferase inhibitors, BIX-01294 and RG108 combination with } \\
\text { factors OK enhance reprogramming efficiency } 30 \text { times more than OK }\end{array}$ & Shi et al., 2008a \\
\hline & $5^{\prime}$-azaC & $\begin{array}{l}\text { DNA methyltransferase inhibitor, increase efficiency and full repro- } \\
\text { gramming }\end{array}$ & Huangfu et al., 2008a \\
\hline & Dexamethasone & Steroid glucocorticoid, enhance the effect of 5 '-azacytidine & Huangfu et al., 2008a \\
\hline & VPA & $\begin{array}{l}\text { Histone deacetylase inhibitor, increase efficiency by more than } 100 \text {-fold } \\
\text { and replace Klf4 and Myc }\end{array}$ & $\begin{array}{l}\text { Huangfu et al., } 2008 a \\
2008 b\end{array}$ \\
\hline & TSA & $\begin{array}{l}\text { Histone deacetylase inhibitor, increase reprogramming efficiency in } \\
\text { nuclear transfer and iPSCs }\end{array}$ & $\begin{array}{l}\text { Kishigami et al., 2006; } \\
\text { Huangfu et al., 2008a }\end{array}$ \\
\hline & SAHA & Histone deacetylase inhibitor & Huangfu et al., 2008a \\
\hline & A-83-01 & $\begin{array}{l}\text { TGF- } \beta \text { inhibitor, together with LIF and } 2 i \text { to maintain mESC like rat and } \\
\text { human iPSCs }\end{array}$ & Li et al., 2009b \\
\hline & Vitamin C & $\begin{array}{l}\text { Vitamin C enhances the reprogramming efficiency of mouse and human } \\
\text { fibroblasts transduced with three OSK or four OSKM factors and vitamin } \\
\mathrm{C} \text { can alleviate cell senescence by p53 repression and may accelerate } \\
\text { reprogramming by synergizing with epigenetic regulators. }\end{array}$ & $\begin{array}{l}\text { Esteban et al., 2010; } \\
\text { Shi et al., } 2010\end{array}$ \\
\hline \multirow[t]{3}{*}{ Signaling pathway } & Wnt & $\begin{array}{l}\text { Cyclic activation of Wnt/beta-catenin signaling in ESCs with Wnt3a } \\
\text { strikingly enhances the ability of ESCs to reprogram somatic cells after } \\
\text { fusion; Wnt3a conditioned medium promoted the reprogramming } \\
\text { OSK-MEFs by } 20 \text { fold }\end{array}$ & $\begin{array}{l}\text { Lluis et al., 2008; } \\
\text { Marson et al., } 2008\end{array}$ \\
\hline & P53 & $\begin{array}{l}\text { OSKM together with p53 siRNA+UTF1 increase the efficiency of highly } \\
\text { AP-positive colony by more than } 200 \text { times compared with just using } \\
\text { OSKM; The suppression of p53 also increased the efficiency of mouse } \\
\text { and human iPS cell generation; In murine cells, Arf, rather than Ink4a, is } \\
\text { the main barrier to reprogramming by activation of p53 and p21, } \\
\text { whereas, in human fibroblasts, INK4a is more important than ARF. }\end{array}$ & $\begin{array}{l}\text { Zhao et al., 2008; Hong } \\
\text { et al., 2009; Kawamura } \\
\text { et al., 2009; Li et al., } \\
\text { 2009a; Marion et al., } \\
\text { 2009; Utikal et al., } 2009\end{array}$ \\
\hline & TGF- $\beta$ & $\begin{array}{l}\text { Inhibition of TGF- } \beta \text { signaling promotes the completion of reprogram- } \\
\text { ming through induction of the transcription factor Nanog. Any one of } \\
\text { TGF- } \beta \text { inhibitor E- } 616452 \text { ("RepSox") or E- } 616451 \text { can replace Sox } 2\end{array}$ & Ichida et al., 2009 \\
\hline
\end{tabular}

Reprogramming is the iterative replacement of the original transcriptional program present within the differentiated starting cell with the program present within a pluripotential cell: a key step is the silencing of the molecular program of the donor cell. microRNAs are small non-coding RNAs, each of which binds and suppresses hundreds of specific mRNAs, thus drastically altering the transcriptome and molecular constitution of a cell (Melton et al., 2010). Thus, microRNAs are 
attractive candidates for factors that can silence the active transcriptional program of the starting cell, thus facilitating reprogramming and establishment of a novel program. To this end, microRNAs expressed within ES cells that possibly suppress differentiation programs have emerged as possible enhancers of reprogramming. Indeed, several ES-expressed microRNAs, such as miR-291-3p, miR-294, miR-295, and miR-302, are capable of enhancing reprogramming efficiency when overexpressed (Lin et al., 2008; Judson et al., 2009; Melton et al., 2010) (Table 4).

A variety of chemical compounds have also been found to enhance reprogramming efficiency or even to replace specific reprogramming transcription factors. These chemical compounds include a DNA methyltransferase inhibitor, histone deacetylase inhibitors, a histone methyltransferase inhibitor, a MAPK/ERK inhibitor, a GSK3 inhibitor, a calcium channel agonist, a steroid glucocorticoid, and Vitamin C (Table 4).

Usage of these chemical compounds to potentiate reprogramming is particularly appealing given their ease of use and the fact that they guaranteedly do not introduce any genetic modifications, as do any reprogramming methods that involve delivery of genetic factors. Nevertheless, from a mechanistic perspective, it is currently unknown whether small molecules alone can recapitulate the series of transcriptional and epigenetic changes brought about by the reprogramming transcription factors, thus making it uncertain if one day it will be possible to reprogram differentiated cells solely by a cocktail of chemical compounds. Furthermore, an important caveat to the usage of chemical compounds that are epigenetic modifiers is that their broad and nonspecific effects may elicit an overall dysregulation of gene expression (Maherali and Hochedlinger, 2008; Feng et al., 2009b).

Extracellular signaling pathways such as the Wnt pathway and the TGF- $\beta$ pathway have also been shown to have a role in reprogramming; specifically, activation of $\mathrm{Wnt} / \beta$-catenin signaling likely enhances reprogramming efficiency, whereas inhibition of TGF- $\beta$ signaling also enhances reprogramming efficiency and can also replace the reprogramming factor Sox2 (Marson et al., 2008; Ichida et al., 2009). Although the mechanistic role by which TGF- $\beta$ inhibition facilitates reprogramming has remained a topic of debate, the broadly conserved role of Wnt signaling in maintaining human ES cells, mouse ES cells, and a variety of adult stem cells suggests that Wnt activation during reprogramming may directly activate various pluripotency genes (Miyabayashi et al., 2007).

Another recent major factor that has emerged is the tumor suppressor $p 53$. Five recent publications in Nature have shown that suppression of the p53 pathway leads to a marked improvement in the efficiency and kinetics of human and mouse cell reprogramming (Hong et al., 2009; Kawamura et al., 2009; Li et al., 2009a; Marion et al., 2009; Utikal et al., 2009). Given that p53 is a stress response protein capable of effecting apoptosis or senescence, suppressing p53 overcomes such barriers, likely explaining the enhanced reprogramming efficiency observed after p53 suppression. Nevertheless, it is important to note that $p 53$ genetic deletion leads to the generation of iPSCs with uniformly increased genomic damage (given the role of $p 53$ in safeguarding genomic stability)(Krizhanovsky and Lowe, 2009); thus its permanent inactivation is undesirable in the production of iPSCs for therapeutic means.

\section{IMPROVING THE QUALITY OF IPS CELLS}

Although many reprogramming agents, including transcription factors, chemical compounds, microRNAs and signaling pathway modulators, have been identified to facilitate or potentiate pluripotent reprogramming, very few studies have carefully examined the quality of iPSCs. Although iPSCs have a distinct morphology and express molecular markers similar to ESCs, their capacity for multilineage differentiation after embryo complementation is extremely varied (Wernig et al., 2007; Shi et al., 2008a; Feng et al., 2009a). During reprogramming to pluripotency, there were the events of copy number variation, mutations of protein-coding regions, karotypic abnormalities and aberrant slicing of imprinting genes in iPS cells (Stadtfeld et al., 2010; Gore et al., 2011; Hussein et al., 2011). This has led to cogent allegations that many iPSC lines indeed are not authentic pluripotent stem cell lines.

In mouse, iPS cells with good quality can pass germline transmission and can produce fully iPSCs mice by tetraploid complement. The germline contribution and the ability of producing iPSCs mice can be as standards to examine the iPSCs quality. We generated panels of different iPSC lines by different combinations of reprogramming factors and assessed whether inclusion of particular factors could lead to a uniform increase in the "quality" of iPSC lines. To this end, we found that overexpression of the pluripotency-associated transcription factor $T b \times 3$ in combination with Oct4, Sox2, and KIf4 ("OSKT") led to iPSC lines with enhanced contribution to chimeras and enhanced germline contribution as compared to traditional OSK-derived iPSC lines (Han et al., 2010). Thus, inclusion of $T b \times 3$ leads to a significant increase in the "quality" of mouse iPSC lines.

What is the molecular mechanism by which $T b \times 3$ effects a uniform improvement in the pluripotential characteristics of iPSC lines? Through genome-wide chromatin immunoprecipitation-sequencing (chIP-seq) analysis of Tbx3-binding sites, we found that in ES cells, Tbx3 bound the important ES genes Oct4, Sox2, Sall4, Lefty1, Lefty2, and Zfp42, as well as the reprogramming factors KIf2, KIf4, KIf5, c-Myc, and $n-M y c$. However, it remains to be determined whether or not overexpression of $T b \times 3$ during reprogramming actually leads to upregulation of these pluripotency genes (thus increasing iPSC "quality"). Tbx3 is a member of a family of transcription factors that share a highly conserved DNA-binding domain known as the T-domain. Tbx 3 is necessary for safeguarding the pluripotency of mouse ES cells, as its knockdown elicits 
differentiation (Ivanova et al., 2006). It appears to have pleiotrophic roles, as it is also required for mammary bud development and limb development (Carlson et al., 2002; Esteban et al., 2009; Graf et al., 2009; Maekawa et al., 2011). Furthermore, overexpression of $T b x 3$ in conjunction with $M y c$ or oncogenic Ras leads to the efficient oncogenic transformation of mouse fibroblasts; it appears that Tbx3's role in oncogenic cooperation is to inhibit the induction of $p 53$ and $p 19^{A R F}$ that is typically triggered by Myc and Ras (Carlson et al., 2002).

Maekawa et al. found that Glis1 markedly enhances the generation of iPSCs from both mouse and human fibroblasts when it is expressed together with OSK. Even more importantly, this four transcription factors generated mouse iPSCs can form germline-competent chimaeras (Maekawa et al., 2011). To undertake further research of the mechanism, they found Glis1 promotes multiple pro-reprogramming pathways, including Myc, Nanog, Lin28, Wnt, Essrb and the mesenchymal-epithelial transition, to promote the direct reprogramming of somatic cells during iPSC generation. In addition, Vitamin $C$ was found to improve the quality of iPS cells by regulation of the $\mathrm{Jhdm} 1 \mathrm{a} / 1 \mathrm{~b}$ pathways (Esteban and Pei, 2012).

\section{FUTURE DIRECTIONS}

Pluripotential reprogramming by transcription factor overexpression presents an ideal method to generate pluripotent stem cell lines bereft of embryonic tissue. Furthermore, the generation of patient-specific iPSC lines enables autologous cell replacement therapies for human patients, as well as opportunities to generate novel in vitro models of human genetic diseases. Here, we have highlighted two important issues that must be circumvented prior to the widespread therapeutic employment of iPSC technology: namely, the inefficiency of iPSC generation and the inconsistent pluripotent characteristics of many iPSC lines.

Through pluripotential reprogramming may be efficiently achieved through a variety of technical methods, such as method of reprogramming factor delivery, choice of starting cell type, and inclusion of additional genetic factors or chemical compounds, the latter issue-that of iPSC quality - presently remains inadequately addressed. Methods to routinely assess the "quality" of generated iPSC lines remain to be developed as well as factor combinations that lead to a uniform increase in the proportion of authentically pluripotent iPSC lines that are generated.

A defined cadre of transcription factors and epigenetic regulators confer ES cells with their authentic pluripotent condition-we are attaining an increasingly detailed understanding of which nuclear factors safeguard ES cell pluripotency and the mechanisms by which they act to maintain pluripotency. The authentic pluripotency of ES cells should be recreatable within iPSCs by the expression of all nuclear factors that confer ES cells with their own genuine pluripotency. We intuit that a rational strategy to uniformly enhance iPSC quality will involve increasing molecular definition of the factors that underlay ES cell pluripotency combined with the inclusion of such ES cell nuclear factors within the cocktail of factors used to reprogram differentiated cells (Fig. 1).
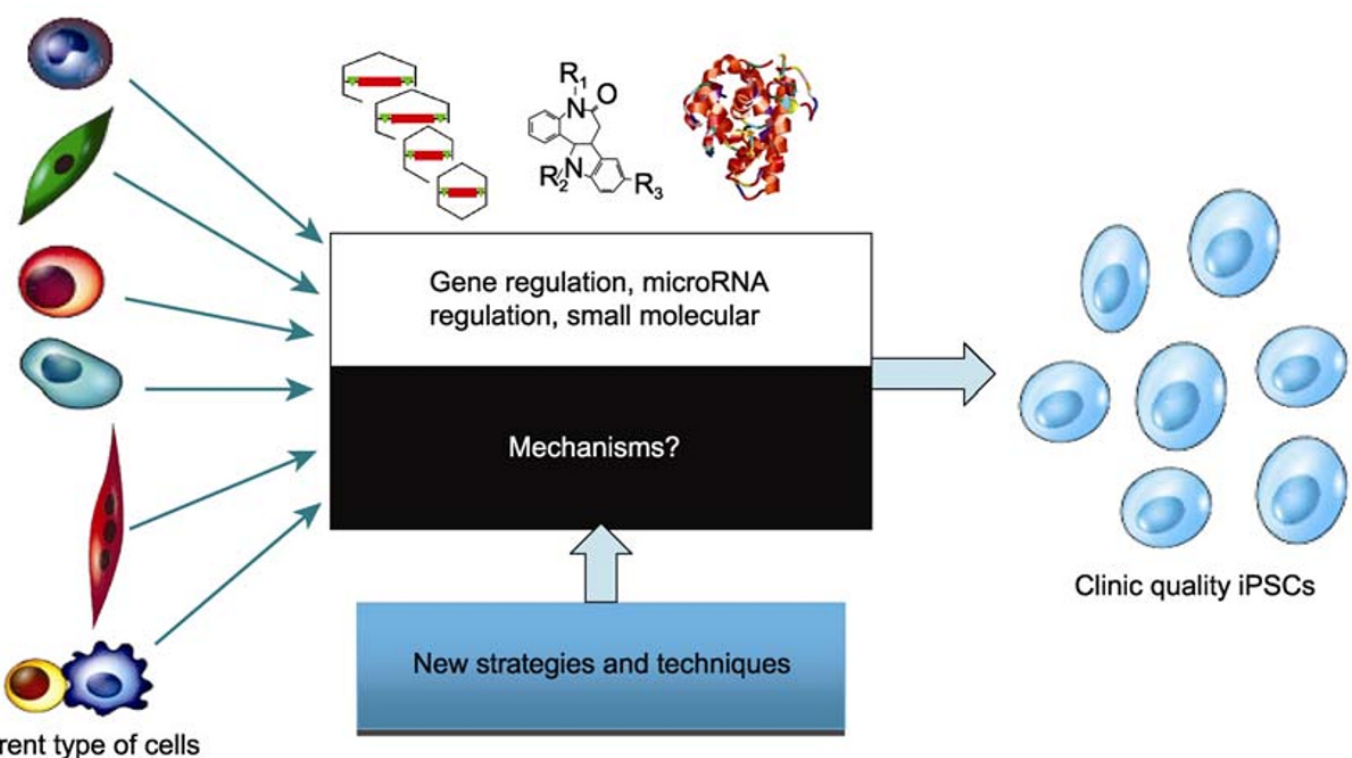

Clinic quality iPSCs

Different type of cells

Figure 1. Exploration of the mechanisms for reprogramming different cell type to unitive high quality iPSCs. Different strategies and factors affect the generating efficiency and quality of iPSCs have been identified and there are still lots of unknown for the mechanisms, which is the key thing we should focus on before the clinic application in future (Graf and Enver, 2009). 


\section{ACKNOWLEDGEMENTS}

Decribed here is partially funded by Program for New Century Excellent Talents in University (NCET-11-0482) and by the National Key Basic Research and Development Program of China (Nos. 2009CB941003, 2011CBA01102, 2011CBA01001, and 2010CB945404). We would like to thank Professor Bing Lim and Professor Ning Li for their discussions and suggestions.

\section{REFERENCES}

Aasen, T., Raya, A., Barrero, M.J., Garreta, E., Consiglio, A., Gonzalez, F., Vassena, R., Bilic, J., Pekarik, V., Tiscornia, G., et al. (2008). Efficient and rapid generation of induced pluripotent stem cells from human keratinocytes. Nat Biotechnol 26, 1276-1284.

Aoi, T., Yae, K., Nakagawa, M., Ichisaka, T., Okita, K., Takahashi, K., Chiba, T., and Yamanaka, S. (2008). Generation of pluripotent stem cells from adult mouse liver and stomach cells. Science 321 , 699-702.

Blelloch, R., Venere, M., Yen, J., and Ramalho-Santos, M. (2007). Generation of induced pluripotent stem cells in the absence of drug selection. Cell Stem Cell 1, 245-247.

Bosnali, M., and Edenhofer, F. (2008). Generation of transducible versions of transcription factors Oct4 and Sox2. Biol Chem 389, 851-861.

Brambrink, T., Foreman, R., Welstead, G.G., Lengner, C.J., Wernig, M., Suh, H., and Jaenisch, R. (2008). Sequential expression of pluripotency markers during direct reprogramming of mouse somatic cells. Cell Stem Cell 2, 151-159.

Carlson, H., Ota, S., Song, Y., Chen, Y., and Hurlin, P.J. (2002). Tbx3 impinges on the p53 pathway to suppress apoptosis, facilitate cell transformation and block myogenic differentiation. Oncogene 21, 3827-3835.

Chang, C.W., Lai, Y.S., Pawlik, K.M., Liu, K., Sun, C.W., Li, C., Schoeb, T.R., and Townes, T.M. (2009). Polycistronic lentiviral vector for "hit and run" reprogramming of adult skin fibroblasts to induced pluripotent stem cells. Stem Cells 27, 1042-1049.

Eminli, S., Foudi, A., Stadtfeld, M., Maherali, N., Ahfeldt, T., Mostoslavsky, G., Hock, H., and Hochedlinger, K. (2009). Differentiation stage determines potential of hematopoietic cells for reprogramming into induced pluripotent stem cells. Nat Genet 41, 968-976.

Eminli, S., Utikal, J., Arnold, K., Jaenisch, R., and Hochedlinger, K. (2008). Reprogramming of neural progenitor cells into induced pluripotent stem cells in the absence of exogenous Sox2 expression. Stem Cells 26, 2467-2474.

Esteban, M.A., and Pei, D. (2012). Vitamin C improves the quality of somatic cell reprogramming. Nat Genet 44, 366-367.

Esteban, M.A., Wang, T., Qin, B., Yang, J., Qin, D., Cai, J., Li, W., Weng, Z., Chen, J., Ni, S., et al. (2010). Vitamin C enhances the generation of mouse and human induced pluripotent stem cells. Cell Stem Cell 6, 71-79.

Esteban, M.A., Xu, J., Yang, J., Peng, M., Qin, D., Li, W., Jiang, Z., Chen, J., Deng, K., Zhong, M., et al. (2009). Generation of induced pluripotent stem cell lines from Tibetan miniature pig. J Biol Chem 284, 17634-17640.

Ezashi, T., Telugu, B.P., Alexenko, A.P., Sachdev, S., Sinha, S., and
Roberts, R.M. (2009). Derivation of induced pluripotent stem cells from pig somatic cells. Proc Natl Acad Sci U S A 106, 10993-10998.

Feng, B., Jiang, J., Kraus, P., Ng, J.H., Heng, J.C., Chan, Y.S., Yaw, L.P., Zhang, W., Loh, Y.H., Han, J., et al. (2009a). Reprogramming of fibroblasts into induced pluripotent stem cells with orphan nuclear receptor Esrrb. Nat Cell Biol 11, 197-203.

Feng, B., Ng, J.H., Heng, J.C., and Ng, H.H. (2009b). Molecules that promote or enhance reprogramming of somatic cells to induced pluripotent stem cells. Cell Stem Cell 4, 301-312.

Fusaki, N., Ban, H., Nishiyama, A., Saeki, K., and Hasegawa, M. (2009). Efficient induction of transgene-free human pluripotent stem cells using a vector based on Sendai virus, an RNA virus that does not integrate into the host genome. Proc Jpn Acad Ser B Phys Biol Sci 85, 348-362.

Gonzalez, F., Barragan Monasterio, M., Tiscornia, G., Montserrat Pulido, N., Vassena, R., Batlle Morera, L., Rodriguez Piza, I., and Izpisua Belmonte, J.C. (2009). Generation of mouse-induced pluripotent stem cells by transient expression of a single nonviral polycistronic vector. Proc Natl Acad Sci U S A 106, 8918-8922.

Gore, A., Li, Z., Fung, H.L., Young, J.E., Agarwal, S., Antosiewicz-Bourget, J., Canto, I., Giorgetti, A., Israel, M.A., Kiskinis, E., et al. (2011). Somatic coding mutations in human induced pluripotent stem cells. Nature 471, 63-67.

Graf, T., and Enver, T. (2009). Forcing cells to change lineages. Nature 462, 587-594.

Han, J., Yuan, P., Yang, H., Zhang, J., Soh, B.S., Li, P., Lim, S.L., Cao, S., Tay, J., Orlov, Y.L., et al. (2010). Tbx3 improves the germ-line competency of induced pluripotent stem cells. Nature 463, 1096-1100.

Hanna, J., Markoulaki, S., Schorderet, P., Carey, B.W., Beard, C., Wernig, M., Creyghton, M.P., Steine, E.J., Cassady, J.P., Foreman, R., et al. (2008). Direct reprogramming of terminally differentiated mature B lymphocytes to pluripotency. Cell 133, 250-264.

Heng, J.C., Feng, B., Han, J., Jiang, J., Kraus, P., Ng, J.H., Orlov, Y.L., Huss, M., Yang, L., Lufkin, T., et al. (2010). The nuclear receptor $\mathrm{Nr} 5 \mathrm{a} 2$ can replace Oct4 in the reprogramming of murine somatic cells to pluripotent cells. Cell Stem Cell 6, 167-174.

Hochedlinger, K., and Jaenisch, R. (2006). Nuclear reprogramming and pluripotency. Nature 441, 1061-1067.

Hong, H., Takahashi, K., Ichisaka, T., Aoi, T., Kanagawa, O., Nakagawa, M., Okita, K., and Yamanaka, S. (2009). Suppression of induced pluripotent stem cell generation by the p53-p21 pathway. Nature 460, 1132-1135.

Huangfu, D., Maehr, R., Guo, W., Eijkelenboom, A., Snitow, M., Chen, A.E., and Melton, D.A. (2008a). Induction of pluripotent stem cells by defined factors is greatly improved by small-molecule compounds. Nat Biotechnol 26, 795-797.

Huangfu, D., Osafune, K., Maehr, R., Guo, W., Eijkelenboom, A., Chen, S., Muhlestein, W., and Melton, D.A. (2008b). Induction of pluripotent stem cells from primary human fibroblasts with only Oct4 and Sox2. Nat Biotechnol 26, 1269-1275.

Hussein, S.M., Batada, N.N., Vuoristo, S., Ching, R.W., Autio, R., Narva, E., Ng, S., Sourour, M., Hamalainen, R., Olsson, C., et al. (2011). Copy number variation and selection during reprogramming to pluripotency. Nature $471,58-62$. 
Ichida, J.K., Blanchard, J., Lam, K., Son, E.Y., Chung, J.E., Egli, D., Loh, K.M., Carter, A.C., Di Giorgio, F.P., Koszka, K., et al. (2009). A small-molecule inhibitor of tgf-Beta signaling replaces sox2 in reprogramming by inducing nanog. Cell Stem Cell 5, 491-503.

Ivanova, N., Dobrin, R., Lu, R., Kotenko, I., Levorse, J., DeCoste, C., Schafer, X., Lun, Y., and Lemischka, I.R. (2006). Dissecting self-renewal in stem cells with RNA interference. Nature 442, 533-538.

Judson, R.L., Babiarz, J.E., Venere, M., and Blelloch, R. (2009). Embryonic stem cell-specific microRNAs promote induced pluripotency. Nat Biotechnol 27, 459-461.

Kaji, K., Norrby, K., Paca, A., Mileikovsky, M., Mohseni, P., and Woltjen, K. (2009). Virus-free induction of pluripotency and subsequent excision of reprogramming factors. Nature 458, 771-775.

Kawamura, T., Suzuki, J., Wang, Y.V., Menendez, S., Morera, L.B., Raya, A., Wahl, G.M., and Belmonte, J.C. (2009). Linking the p53 tumour suppressor pathway to somatic cell reprogramming. Nature 460, 1140-1144.

Keefer, C.L., Pant, D., Blomberg, L., and Talbot, N.C. (2007). Challenges and prospects for the establishment of embryonic stem cell lines of domesticated ungulates. Anim Reprod Sci 98, 147-168.

Kim, J.B., Greber, B., Arauzo-Bravo, M.J., Meyer, J., Park, K.I., Zaehres, H., and Scholer, H.R. (2009a). Direct reprogramming of human neural stem cells by OCT4. Nature 461, 649-643.

Kim, J.B., Sebastiano, V., Wu, G., Arauzo-Bravo, M.J., Sasse, P., Gentile, L., Ko, K., Ruau, D., Ehrich, M., van den Boom, D., et al. (2009b). Oct4-induced pluripotency in adult neural stem cells. Cell 136, 411-419.

Kim, J.B., Zaehres, H., Wu, G., Gentile, L., Ko, K., Sebastiano, V., Arauzo-Bravo, M.J., Ruau, D., Han, D.W., Zenke, M., et al. (2008) Pluripotent stem cells induced from adult neural stem cells by reprogramming with two factors. Nature 454, 646-650.

Kishigami, S., Mizutani, E., Ohta, H., Hikichi, T., Thuan, N.V., Wakayama, S., Bui, H.T., and Wakayama, T. (2006). Significant improvement of mouse cloning technique by treatment with trichostatin A after somatic nuclear transfer. Biochem Biophys Res Commun 340, 183-189.

Krizhanovsky, V., and Lowe, S.W. (2009). Stem cells: The promises and perils of p53. Nature 460, 1085-1086.

Kustikova, O., Fehse, B., Modlich, U., Yang, M., Dullmann, J., Kamino, K., von Neuhoff, N., Schlegelberger, B., Li, Z., and Baum, C. (2005). Clonal dominance of hematopoietic stem cells triggered by retroviral gene marking. Science 308, 1171-1174.

Li, H., Collado, M., Villasante, A., Strati, K., Ortega, S., Canamero, M., Blasco, M.A., and Serrano, M. (2009a). The Ink4/Arf locus is a barrier for iPS cell reprogramming. Nature 460, 1136-1139.

Li, W., Wei, W., Zhu, S., Zhu, J., Shi, Y., Lin, T., Hao, E., Hayek, A., Deng, H., and Ding, S. (2009b). Generation of rat and human induced pluripotent stem cells by combining genetic reprogramming and chemical inhibitors. Cell Stem Cell 4, 16-19.

Liao, J., Cui, C., Chen, S., Ren, J., Chen, J., Gao, Y., Li, H., Jia, N., Cheng, L., Xiao, H., et al. (2009). Generation of induced pluripotent stem cell lines from adult rat cells. Cell Stem Cell 4, 11-15.

Lin, S.L., Chang, D.C., Chang-Lin, S., Lin, C.H., Wu, D.T., Chen, D.T., and Ying, S.Y. (2008). Mir-302 reprograms human skin cancer cells into a pluripotent ES-cell-like state. RNA 14, 2115-2124.

Liu, H., Zhu, F., Yong, J., Zhang, P., Hou, P., Li, H., Jiang, W., Cai, J., Liu, M., Cui, K., et al. (2008). Generation of induced pluripotent stem cells from adult rhesus monkey fibroblasts. Cell Stem Cell 3, 587-590.

Lluis, F., Pedone, E., Pepe, S., and Cosma, M.P. (2008). Periodic activation of Wnt/beta-catenin signaling enhances somatic cell reprogramming mediated by cell fusion. Cell Stem Cell 3, 493-507.

Loh, Y.H., Agarwal, S., Park, I.H., Urbach, A., Huo, H., Heffner, G.C., Kim, K., Miller, J.D., Ng, K., and Daley, G.Q. (2009). Generation of induced pluripotent stem cells from human blood. Blood 113, 5476-5479.

Lowry, W.E., Richter, L., Yachechko, R., Pyle, A.D., Tchieu, J., Sridharan, R., Clark, A.T., and Plath, K. (2008). Generation of human induced pluripotent stem cells from dermal fibroblasts. Proc Natl Acad Sci U S A 105, 2883-2888.

Lyssiotis, C.A., Foreman, R.K., Staerk, J., Garcia, M., Mathur, D., Markoulaki, S., Hanna, J., Lairson, L.L., Charette, B.D., Bouchez, L.C., et al. (2009). Reprogramming of murine fibroblasts to induced pluripotent stem cells with chemical complementation of KIf4. Proc Natl Acad Sci U S A 106, 8912-8917.

Maekawa, M., Yamaguchi, K., Nakamura, T., Shibukawa, R., Kodanaka, I., Ichisaka, T., Kawamura, Y., Mochizuki, H., Goshima, N., and Yamanaka, S. (2011). Direct reprogramming of somatic cells is promoted by maternal transcription factor Glis1. Nature 474, 225-229.

Maherali, N., and Hochedlinger, K. (2008). Guidelines and techniques for the generation of induced pluripotent stem cells. Cell Stem Cell 3, 595-605.

Marion, R.M., Strati, K., Li, H., Murga, M., Blanco, R., Ortega, S., Fernandez-Capetillo, O., Serrano, M., and Blasco, M.A. (2009). A p53-mediated DNA damage response limits reprogramming to ensure iPS cell genomic integrity. Nature 460, 1149-1153.

Markoulaki, S., Hanna, J., Beard, C., Carey, B.W., Cheng, A.W., Lengner, C.J., Dausman, J.A., Fu, D., Gao, Q., Wu, S., et al. (2009). Transgenic mice with defined combinations of drug-inducible reprogramming factors. Nat Biotechnol 27, 169-171.

Marson, A., Foreman, R., Chevalier, B., Bilodeau, S., Kahn, M., Young, R.A., and Jaenisch, R. (2008). Wnt signaling promotes reprogramming of somatic cells to pluripotency. Cell Stem Cell 3, 132-135.

Matsui, T., Leung, D., Miyashita, H., Maksakova, I.A., Miyachi, H., Kimura, H., Tachibana, M., Lorincz, M.C., and Shinkai, Y. (2010). Proviral silencing in embryonic stem cells requires the histone methyltransferase ESET. Nature 464, 927-931.

Melton, C., Judson, R.L., and Blelloch, R. (2010). Opposing microRNA families regulate self-renewal in mouse embryonic stem cells. Nature 463, 621-626.

Miyabayashi, T., Teo, J.L., Yamamoto, M., McMillan, M., Nguyen, C., and Kahn, M. (2007). Wnt/beta-catenin/CBP signaling maintains long-term murine embryonic stem cell pluripotency. Proc Natl Acad Sci U S A 104, 5668-5673.

Nakagawa, M., Koyanagi, M., Tanabe, K., Takahashi, K., Ichisaka, T., Aoi, T., Okita, K., Mochiduki, Y., Takizawa, N., and Yamanaka, S. 
(2008). Generation of induced pluripotent stem cells without Myc from mouse and human fibroblasts. Nat Biotechnol 26, 101-106.

Okita, K., Nakagawa, M., Hyenjong, H., Ichisaka, T., and Yamanaka, S. (2008). Generation of mouse induced pluripotent stem cells without viral vectors. Science 322, 949-953.

Park, I.H., Zhao, R., West, J.A., Yabuuchi, A., Huo, H., Ince, T.A., Lerou, P.H., Lensch, M.W., and Daley, G.Q. (2008). Reprogramming of human somatic cells to pluripotency with defined factors. Nature 451, 141-146.

Qin, D., Gan, Y., Shao, K., Wang, H., Li, W., Wang, T., He, W., Xu, J., Zhang, Y., Kou, Z., et al. (2008). Mouse meningiocytes express Sox2 and yield high efficiency of chimeras after nuclear reprogramming with exogenous factors. J Biol Chem 283, 33730-33735.

Shi, Y., Desponts, C., Do, J.T., Hahm, H.S., Scholer, H.R., and Ding, S. (2008a). Induction of pluripotent stem cells from mouse embryonic fibroblasts by Oct4 and Klf4 with small-molecule compounds. Cell Stem Cell 3, 568-574.

Shi, Y., Do, J.T., Desponts, C., Hahm, H.S., Scholer, H.R., and Ding, S. (2008b). A combined chemical and genetic approach for the generation of induced pluripotent stem cells. Cell Stem Cell 2, 525-528.

Shi, Y., Zhao, Y., and Deng, H. (2010). Powering reprogramming with vitamin C. Cell Stem Cell 6, 1-2.

Silva, J., Barrandon, O., Nichols, J., Kawaguchi, J., Theunissen, T.W., and Smith, A. (2008). Promotion of reprogramming to ground state pluripotency by signal inhibition. PLoS Biol 6, e253.

Soldner, F., Hockemeyer, D., Beard, C., Gao, Q., Bell, G.W., Cook, E.G., Hargus, G., Blak, A., Cooper, O., Mitalipova, M., et al. (2009). Parkinson's disease patient-derived induced pluripotent stem cells free of viral reprogramming factors. Cell 136, 964-977.

Stadtfeld, M., Apostolou, E., Akutsu, H., Fukuda, A., Follett, P., Natesan, S., Kono, T., Shioda, T., and Hochedlinger, K. (2010). Aberrant silencing of imprinted genes on chromosome 12qF1 in mouse induced pluripotent stem cells. Nature 465, 175-181.

Stadtfeld, M., Brennand, K., and Hochedlinger, K. (2008a). Reprogramming of pancreatic beta cells into induced pluripotent stem cells. Curr Biol 18, 890-894.

Stadtfeld, M., Maherali, N., Breault, D.T., and Hochedlinger, K. (2008b). Defining molecular cornerstones during fibroblast to iPS cell reprogramming in mouse. Cell Stem Cell 2, 230-240.

Stadtfeld, M., Nagaya, M., Utikal, J., Weir, G., and Hochedlinger, K. (2008c). Induced pluripotent stem cells generated without viral integration. Science 322, 945-949.

Takahashi, K., Tanabe, K., Ohnuki, M., Narita, M., Ichisaka, T., Tomoda, K., and Yamanaka, S. (2007). Induction of pluripotent stem cells from adult human fibroblasts by defined factors. Cell 131, 861-872.

Takahashi, K., and Yamanaka, S. (2006). Induction of pluripotent stem cells from mouse embryonic and adult fibroblast cultures by defined factors. Cell 126, 663-676.

Trounson, A. (2009). Rats, cats, and elephants, but still no unicorn: induced pluripotent stem cells from new species. Cell Stem Cell 4, 3-4.

Utikal, J., Polo, J.M., Stadtfeld, M., Maherali, N., Kulalert, W., Walsh, R.M., Khalil, A., Rheinwald, J.G., and Hochedlinger, K. (2009). Immortalization eliminates a roadblock during cellular reprogramming into iPS cells. Nature 460, 1145-1148.

Varas, F., Stadtfeld, M., de Andres-Aguayo, L., Maherali, N., di Tullio, A., Pantano, L., Notredame, C., Hochedlinger, K., and Graf, T. (2009). Fibroblast-derived induced pluripotent stem cells show no common retroviral vector insertions. Stem Cells 27, 300-306.

Wernig, M., Lengner, C.J., Hanna, J., Lodato, M.A., Steine, E., Foreman, R., Staerk, J., Markoulaki, S., and Jaenisch, R. (2008). A drug-inducible transgenic system for direct reprogramming of multiple somatic cell types. Nat Biotechnol 26, 916-924.

Wernig, M., Meissner, A., Foreman, R., Brambrink, T., Ku, M., Hochedlinger, K., Bernstein, B.E., and Jaenisch, R. (2007). In vitro reprogramming of fibroblasts into a pluripotent ES-cell-like state. Nature 448, 318-324.

West, F.D., Terlouw, S.L., Kwon, D.J., Mumaw, J.L., Dhara, S.K., Hasneen, K., Dobrinsky, J.R., and Stice, S.L. (2010). Porcine induced pluripotent stem cells produce chimeric offspring. Stem Cells Dev 19, 1211-1220.

Wobus, A.M., and Boheler, K.R. (2005). Embryonic stem cells: prospects for developmental biology and cell therapy. Physiol Rev 85, 635-678.

Woltjen, K., Michael, I.P., Mohseni, P., Desai, R., Mileikovsky, M., Hamalainen, R., Cowling, R., Wang, W., Liu, P., Gertsenstein, M., et al. (2009). piggyBac transposition reprograms fibroblasts to induced pluripotent stem cells. Nature 458, 766-770.

Wu, Z., Chen, J., Ren, J., Bao, L., Liao, J., Cui, C., Rao, L., Li, H., Gu, Y., Dai, H., et al. (2009). Generation of pig induced pluripotent stem cells with a drug-inducible system. J Mol Cell Biol 1, 46-54.

Yamanaka, S. (2007). Strategies and new developments in the generation of patient-specific pluripotent stem cells. Cell Stem Cell 1, 39-49.

Yu, J., Hu, K., Smuga-Otto, K., Tian, S., Stewart, R., Slukvin, II, and Thomson, J.A. (2009). Human induced pluripotent stem cells free of vector and transgene sequences. Science 324, 797-801.

Yu, J., Vodyanik, M.A., Smuga-Otto, K., Antosiewicz-Bourget, J., Frane, J.L., Tian, S., Nie, J., Jonsdottir, G.A., Ruotti, V., Stewart, $\mathrm{R}$., et al. (2007). Induced pluripotent stem cell lines derived from human somatic cells. Science 318, 1917-1920.

Zhao, Y., Yin, X., Qin, H., Zhu, F., Liu, H., Yang, W., Zhang, Q., Xiang, C., Hou, P., Song, Z., et al. (2008). Two supporting factors greatly improve the efficiency of human iPSC generation. Cell Stem Cell $3,475-479$. 